\title{
SELF-EMULSIFYING DRUG DELIVERY SYSTEMS (SEDDS): EXCIPIENT SELECTION, FORMULA- TION AND CHARACTERIZATION
}

\author{
Ivaylo Pehlivanov \\ Department of Pharmaceutical Technologies, Faculty of Pharmacy, Medical \\ University, Varna, Bulgaria.
}

\begin{abstract}
There is a great number of active pharmaceutical ingredients (APIs) in development that have low solubility and/or low permeability. The oral administration is usually connected with low bioavailability, high Intra- and intervariability of the plasma levels and lack of dose proportionality. Formulating such APIs in SEDDS ameliorates the solubility, permeability and bioavailability profiles with reproducible plasma concentrations. SEDDS are mixtures of different oils and emulgators, ideally isotropic mixtures. Often they contain co-emulsifiers and co-solvents. After dispersion in the gastric fluids, they self-emulsify to fine $\mathrm{O} /$ $\mathrm{W}$ or $\mathrm{W} / \mathrm{O} / \mathrm{W}$ emulsions having dimensions of the dispersed phase in the range 100-300 $\mathrm{nm}$ and in some cases under $100 \mathrm{~nm}$. Surfactants' concentration, surfactant to oil ratio, emulsion polarity, droplet dimension and surface charge are important parameters that influence API absorption from SEDDS when orally administered. These Drug Delivery Systems can facilitate permeation process, but preferable absorption path is through the lymphatic system that leads to bypassing the hepatic first-pass metabolism. The use of in-vitro dispersion and digestion methods permit to a better understanding of the role of the processes that the lipids undergo in the gastrointestinal tract (GIT) during the solubilization of these systems.

The aim of the article is to present a short overview of SEDDS as a strategy to bioavailability improvement, basic principles of excipient selection during their formulation and their characterisation.
\end{abstract}

Keywords: lipid-based drug delivery systems, SEDDS, SMEDDS, SNEDDS

\section{BACKGROUND}

Among others, the oral route for drug delivery is favorite to patients and industry. Many APIs that are formulated in oral dosage forms are important from a therapeutic point of view but cannot reach their full therapeutic potential because of their low solubility or low permeability. It presents a challenge for the technology pharmacists to provide a sufficiently high bioavailability in these cases.

An already approved instrument used in the orientation in the formulation strategies for given API is the
Biopharmaceutical Classification System (BCS). BCS is a scientific frame that categorizes APIs based on their solubility and their ability to pass over cell membranes combined with in-vitro characteristics like dissolution rate. BCS partitions APIs in four classes based on above-mentioned criteria [1].

One of the most popular approaches is including the drugs into Lipid Based Drug Delivery Systems (LBDDS). Among these, Self-emulsifying Drug Delivery Systems (SEDDS) gain much popularity and can be differentiated to: 1. SEDDS - coarse emulsions, 2. SMEDDS- micro emulsions, 3. SNEDDS - nano emulsions.

Strongly lipophilic APIs (BCS class II) can benefit greatly when they are formulated in a self-emulsifying system because of improved solubility and therefore improved bioavailability. For BCS class II drugs that are very hydrophilic, the permeability is the rate-determining factor for absorption. These substances are usually transported by the paracellular pathway. The limited absorption area and tight junctions are limiting their bioavailability. A possible solution to this problem is including these APIs in SEDDS or SDEDDS (self-double emulsifying drug delivery system).

The little droplets that are formed in the process of self-emulsification promote transport and absorption through alternative paths preferably the lymphatic pathway. In this way, the first pass hepatic metabolism is being bypassed and thus improves the bioavailability of APIs that are inactivated by this process [2].

The SEDDS can find various applications not only in the pharmaceutical but in the food and cosmetic industry as well. Multiple emulsions can be used as taste-masking for unpleasant organoleptic APIs to enhance dermal penetration. Because of their structural characteristics, SEDDS have the potential to be applied in vaccine, enzyme and peptide delivery; these systems have the potential for achieving modified release since the drug located in the inner phase needs to diffuse through different phases prior to reaching the absorption site. In this way, reservoir or extended release systems can be obtained according to the physicochemical properties of drug molecule [3].

The stability of LBDDS is of significant importance in order to be introduced in practice. Emulsions have limited stability because of thermodynamic reasons and is de- 
pendent on surfactants' type and concentration, droplets' size, viscosity, conductivity, phase ratio, etc. [3, 4].

\section{MECHANISM OF SELF-EMULSIFICATION}

Self-emulsifying drug delivery systems (SEDDS) are defined as isotropic mixtures of surfactants, co-emulsifiers (second surfactant or solvent), usually but not always one or more lipids and a drug substance. In aqueous medium SEDDS spontaneously form $\mathrm{O} / \mathrm{W}$ or W/O/W emulsions depending on the formulation. In this process, droplets are formed with dimensions varying between $100-300 \mathrm{~nm}$ to $10-20 \mathrm{~nm}$. The self-emulsification process is related to the free energy change, $\Delta \mathrm{G}$ described as:

$$
\Delta \mathbf{G}=\sum_{i} N_{i} \pi r_{i}^{2} \sigma
$$

Where $N_{i}$ is the number of the droplets, $r_{i}$ is the radius of the droplets, $\sigma$ is the interphase tension. From the equation follows that the spontaneous incrementation of oil/water interphase area is not encouraged when energy levels are high.

For the SEDDS is not yet completely clear the exact mechanism of self-emulsification from a thermodynamical point of view. Pouton [5] considers that the emulsifying properties of the nonionic surfactants may be responsible for the system behavior on phase inversion.

If the temperature of $\mathrm{W} / \mathrm{O}$ systems stabilized with nonionic surfactant is raised to the cloud point, phase inversion is being observed. This explains the fact that the hydration extent of the polyoxyethylene (nonionic) surfactants lowers with the temperature rising. Temperature influences the effective HLB values also which lowers to the point when the surfactant is no longer soluble. The cloud point temperature of a given surfactant is influenced by other excipients such as oils, co-solvents and drug substances. This is the reason why the phase behaviour of every system must be studied [6].

\section{EXCIPIENT SELECTION}

When formulating SEDDS or LBDDS in general, the pharmacist needs to answer some questions: which lipid to use? Which formulation technique to use? How to develop the formulation and scale it up for industrial production?

There is a wide variety of excipients. Since lipids influence the absorption processes, it is necessary to have knowledge about the characteristics of the excipients. Factors that govern the excipient selection for the formulation of LBDDS include: solubility, solubilizing capacity, selfdispersibility and dispersibility potential, digestibility and destiny after digestion, regulatory issues: toxicity, irritation, purity, chemical stability, capsule shell compatibility, fusion temperature, price.

For LBDDS formulation are utilized oils that naturally occur in diet and that contain long and middle chained triglycerides. Many of these lipids are amphiphilic since in their structure are found a fatty acid chain and a hydrophilic portion. The fusion temperature is high if the aliphatic side chains are long but is low if the number of unsaturated bonds is high, which on the other hand, in- creases the oxidation risk. Co-solvents are used in formulation to aid the solubilization and dispersion processes. Ethanol, glycerol, PG, PEG 400 are among excipients that are mostly used.

Problems that arise with co-solvents are loss of solvent capacity after dilution, non-digestibility of some lipids or incompatibility with capsule shell. Hydrophobic surfactants that are being used have HLB values between 8-12. Depending on their grade of ethoxylation, they have limited solubility and therefore are named water dispersible. They form emulsions only after homogenization and do not self-emulsify although they form micelles. Hydrophilic surfactants with HLB $\geq 12$ are mostly used. They form micelles in low concentrations. PEGs and hydrolyzed oils, alcohols or esters and ethylene oxide synthesize them. Other excipients that are used in formulation for stability reasons are antioxidants such as $\alpha$-tocopherols, $\beta$-carotenes, propyl gallate, BHT and BHA [7].

There are different existing classifications of the excipients used in the formulation of LBDDS, but there is none accepted unanimously. Cristie [8] defines lipids as fatty acids and their derivatives, including substances that are biosynthetically or functionally related to them. Small [9] developed the Physico-chemical system for lipid classification, including surfactants based on their polarity and their interaction with water, their behaviour in water and water/air interphase. Griffin [10] proposes an empiric classification system based on hydrophilic-lipophilic balance (HLB) particularly applicable to polar and amphiphilic excipients.

A basic problem with lipid excipients classification is that they are usually made by different components and are characterized by the main.

In 2000 Pouton [11] proposed a classification of the LBDDS divided into four different categories that have been updated in 2006. Based on the properties of a given drug substance, it will be categorized according to BCS. In case improved bioavailability is needed, and LBDDS is chosen, the type and the quantity of the excipients for the formulation are characterized best by one of Pouton's classes. This system is based on the excipients' type and quantity, formulations' behaviour in water, digestion, possibility to prevent precipitation of the drug substance (table 1).

In order for a SEDDS formulation to be successful, excipients' choice should be made in accordance with APIs' properties.

\section{DOSE AND API SOLUBILITY}

When a drug has low solubility and thus low absorption, a strategy of choice is to include it in LBDDS. High lipophilicity $(\log \mathrm{P}>5)$ is needed in order the total of the drug dose to be incorporated in one dosage unit. High dosed drugs are not preferred for the SEDDS. Drug with low permeability $(\log \mathrm{P}<2)$ are better candidates for the SEDDS since the focus during formulation should be the whole solubility/dispersibility force of the system. Drugs that are not well soluble nor in water neither in lipids $(\log \mathrm{P} \sim 2)$ are not good SEDDS candidates since both drug release and drug absorption are dependent on such solubility [9, 12]. 
Table 1. Classification system of lipid formulations

\begin{tabular}{|c|c|c|c|c|c|}
\hline \multirow{2}{*}{$\begin{array}{l}\text { Excipients in } \\
\text { formulation }\end{array}$} & \multicolumn{5}{|c|}{ In formulation content $(\% \mathrm{w} / \mathrm{w})$} \\
\hline & TYPE I & TYPE II & TYPE III A & TYPE III B & TYPE IV \\
\hline $\begin{array}{l}\text { Oils: triglycerides or } \\
\text { mixed mono- and } \\
\text { diglycerides }\end{array}$ & 100 & $40-80$ & $40-80$ & $<20$ & - \\
\hline $\begin{array}{l}\text { Surfactants } \\
(\text { HLB }<12)\end{array}$ & - & $20-60$ & - & - & $0-20$ \\
\hline $\begin{array}{l}\text { Surfactants } \\
(\text { HLB >12) }\end{array}$ & - & - & $20-40$ & $20-50$ & $30-80$ \\
\hline $\begin{array}{l}\text { Hydrophilic co-solvent } \\
\text { (PEG, PG, Transcutol) }\end{array}$ & - & - & $0-40$ & $20-50$ & $0-50$ \\
\hline $\begin{array}{l}\text { Particle dimension after } \\
\text { dispersion }(\mathrm{nm})\end{array}$ & $\begin{array}{c}\text { Coarse } \\
\text { emulsion }\end{array}$ & $100-250$ & $100-250$ & $50-100$ & $<50$ \\
\hline $\begin{array}{l}\text { Importance upon } \\
\text { dispersion in water } \\
\text { medium }\end{array}$ & Limited & $\begin{array}{l}\text { Solubilizing } \\
\text { capacity } \\
\text { remains } \\
\text { unchanged }\end{array}$ & $\begin{array}{c}\text { Some loss of } \\
\text { solubilizing } \\
\text { capacity }\end{array}$ & $\begin{array}{l}\text { Significant phase } \\
\text { change and poten- } \\
\text { tial loss of solubi- } \\
\text { lizing capacity }\end{array}$ & $\begin{array}{l}\text { Significant phase } \\
\text { change and poten- } \\
\text { tial loss of solubi- } \\
\text { lizing capacity }\end{array}$ \\
\hline $\begin{array}{l}\text { Importance of GIT } \\
\text { digestion }\end{array}$ & Significant & $\begin{array}{l}\text { Not important, } \\
\text { but very likely } \\
\text { to occur }\end{array}$ & $\begin{array}{l}\text { Not important, } \\
\text { but very likely } \\
\text { to be inhibited }\end{array}$ & Not necessary & Not necessary \\
\hline Short characteristics & $\begin{array}{l}\text { Excellent } \\
\text { biocompatibility; } \\
\text { digestion via } \\
\text { lipase/co-lipase } \\
\text { in colloidal } \\
\text { state. }\end{array}$ & $\begin{array}{l}\text { Surfactants with } \\
\text { HLB 11; } \\
\text { spontaneously } \\
\text { to coarse O/W } \\
\text { emulsions. }\end{array}$ & $\begin{array}{l}\text { SMEDDS and SN } \\
\text { Subgroups in acc } \\
\text { factant and co-st } \\
\text { Clear to slightly } \\
\text { dispersions }\end{array}$ & $\begin{array}{l}\text { EDDS; } \\
\text { ordance of sur- } \\
\text { rfactant quantity; } \\
\text { palescenting }\end{array}$ & $\begin{array}{l}\text { Most hydrophilic } \\
\text { type LBDDS; } \\
\text { More APIs than } \\
\text { TYPE I; very fine } \\
\text { dispersions, fast } \\
\text { release, increased } \\
\text { absorption. }\end{array}$ \\
\hline
\end{tabular}

Drug solubility in the lipid phase greatly influences SEDDS ability to maintain it solubilized. When an API is being solubilized with the aid of surfactants and cosurfactants in the moment of dilution of SEDDS in water can be observed a lowering in the solubilizing capacity of surfactant/co-surfactant system and subsequently drug precipitation.

A classical method for the determination of a drug solubility is the shake flask method and its variants. Generally, a drug excess is put in a flask containing a determined volume of every excipient. The mixtures are thermostated for at least $24 \mathrm{~h}$ in shaking apparatus at room temperature. Then the samples are centrifuged and filtered. The filtrate is diluted with a suitable solvent and quantitatively analyzed. In case after dilution, the samples are not clear than methanol or ethanol can be used. For example, a mixture $\mathrm{CHCl}_{3}$ /methanol can be added $66 \% \mathrm{v} /$ $\mathrm{v}$ to lipids and $7 \% \mathrm{v} / \mathrm{v}$ to surfactants $[13,14]$.

The results will show in which of the lipids, surfactants and co-surfactants the drug is most soluble.

\section{TERNARY PHASE AND PSEUDOPHASE DIA-} GRAMS

For SEDDS formulation, it is important the construction of Phase/Pseudo-phase diagram using the selected excipients [14]. These experiments can give information about the phase behaviour of the excipients of the future SEDDS formulation.

Ternary diagrams are built starting with only three components: oil, surfactant and water. These 3 phases represent the angles of a triangle where every angle is $100 \%$ pure phase.

In the case of Pseudoternary phase diagrams, one of the angles represents a combination of excipients in different ratios: surfactants/co-surfactants, surfactants/cosolvents, primary emulsion $\mathrm{W} / \mathrm{O}$ or $\mathrm{O} / \mathrm{W}$.

For the Phase diagrams construction usually, water titration method is used. The results of these studies are needed in order to determine as accurately possible oil/ surfactant/co-surfactant/water ratio and determine regions of existence of micro- and nano-emulsions. 
A typical procedure [15] for water titration consist of preparing a series of surfactant and co-surfactant solutions in different ratios: $1: 1,2: 1,3: 1$ etc. After equilibration, these solutions are used to prepare mixtures with the lipidic phase (one or more oils) or with the primary emulsion (for double-emulsifying systems) in w/w ratios: 1:9, $2: 8,3: 7,4: 6,5: 5,6: 4,7: 3,8: 2,9: 1$. To every sample, a water is being added dropwisely from $5 \%$ to $95 \%$ by weight at even time intervals with constant mixing and temperature $\left(\sim 37^{\circ} \mathrm{C}\right)$. The titration is being appreciated visually as turbidity indicates raw emulsion and clear solution indicates isotropic microemulsion. Samples can be analyzed instrumentally using turbidimetry or UV-Vis Spectrophotometry using a wavelength in the visible spectra and as blank is used distilled water.

\section{COMPATIBILITY BETWEEN DRUGS AND}

\section{EXCIPIENTS TESTING}

These studies are performed in order to determine if there are incompatibilities of any kind between drug and excipients. Sachin M.Kohle et al. [16] have reported a compatibility study between Ranithidine and Lecithin, Oleic Acid, SPAN 80, TWEEN 80 for the formulation of solid-SEDDS by means of FT-IR spectroscopy. The described procedure consists in preparing a mixture of Ranitidine and a given excipient. The samples are stored for determined time at $40^{\circ} \mathrm{C}$ and $75 \% \mathrm{RH}$. After that period the reference spectres of Ranitidine and excipients are being compared with those of the mixtures analyzing the characteristic bands. The samples are studied for physical changes such as viscosity, $\mathrm{pH}$ and appearance.

\section{FORMULATION METHODS}

In the literature can be found different techniques to obtain SEDDS depending on their type.

For the O/W SEDDS with lipophilic drug a mixture of oil/s with surfactants and co-surfactants is prepared at temperature $10-20^{\circ} \mathrm{C}$ above the excipients' melting point, typically $50-60{ }^{\circ} \mathrm{C}$. After obtaining a homogeneous mixture, the drug is incorporated with constant mixing at the same temperature until a solution is obtained. Upon storing the obtained formulation at room temperature, no stability issues should be observed.

For the SEDDS (W/O/W) with hydrophilic drugs standard techniques for the preparation of multiple emul- sion are being used.

The double stage emulsifying techniques consist of preparing a primary $\mathrm{W} / \mathrm{O}$ or $\mathrm{O} / \mathrm{W}$ emulsion during the first stage by means of a suitable surfactant system. During the second stage is performed a re-emulsification of the primary emulsion and excess amount of the lipophilic or hydrophilic phase. The result is $\mathrm{W} / \mathrm{O} / \mathrm{W}$ double emulsion.

Emulsification by phase inversion or single stage. The increasing of volume concentration of the disperse phase can lead to a change of the vol/vol ratio, which results in multiple emulsions. Typically the water phase containing hydrophilic surfactant is added to the lipidic one containing lipophilic surfactant. The addition of the water phase is performed slowly during constant mixing at room temperature. At the point which the volume fraction of the hydrophilic surfactants exceeds 0,7 times, the dispersing lipidic phase is substituted by the water containing different number of lipid globular vesicules a state that brings a phase inversion and forming of a multiple emulsion $\mathrm{W} / \mathrm{O} / \mathrm{W}$.

Membrane emulsification. With this technique a W/ $\mathrm{O}$ emulsion as a disperse phase is being extruded through porous glass membrane into external water phase by means of high pressure. The membrane pores' size is defined, controlled and homogenous. The size of the dispersed phase vesicles can be controlled precisely by choosing a membrane with precise pore dimensions since they are related. The relation between the glass membrane's pore size and droplets' diameter of the dispersed phase of the W/O/W emulsion has good linear correlation that can be described by the following equation:

$\mathrm{Y}=5.03 \mathrm{X}+0.19$

Where $\mathrm{X}$ is pores' diameter, $\mathrm{Y}$ is the mean droplet size of the dispersed phase $[3,17]$.

From a practical point of view, a successful SEDDS formulation needs industrial development and scale-up. There are some known techniques applicable to other LBDDS as well. Via these techniques, liquid and semisolid SEDDS can be incorporated into solid dosage forms such as capsules and tablets. The technique selection is dependent upon equipment availability, formulation elements, thermoplastic and rheological properties, equipment's operational parameters as well as compatibility with other excipients necessary for task completion.

Table 2. Techniques to incorporate liquid and semi-solid SEDDS into solid dosage forms [18, 19]

\begin{tabular}{|c|c|c|c|}
\hline Technique & Description & Advantages & Other excipients \\
\hline $\begin{array}{l}\text { Direct capsule } \\
\text { filling }\end{array}$ & $\begin{array}{l}\text { Hard or soft gelatin capsules are filled } \\
\text { with liquid and semisolid SEDDS formu- } \\
\text { lations; the } \Delta \mathrm{T} \text { of the process is usually } \\
2^{\circ} \mathrm{C} \text { above the temperature of the } \\
\text { incrementation of the apparent viscosity } \\
\text { after cooling. }\end{array}$ & $\begin{array}{l}\text { Simple process suitable for low } \\
\text { dosed strong APIs; low operatio- } \\
\text { nal costs; } \\
\text { Potentially high loading with } \\
\text { APIs; good compatibility be- } \\
\text { tween lipids and capsule shell. }\end{array}$ & \\
\hline
\end{tabular}




\begin{tabular}{|c|c|c|c|}
\hline $\begin{array}{l}\text { Adsorption on } \\
\text { solid carriers }\end{array}$ & $\begin{array}{l}\text { Liquid SEDDS formulations are being } \\
\text { adsorbed on solid carriers with the aim to } \\
\text { obtain free flowing powders for capsule } \\
\text { filling or tableting. }\end{array}$ & $\begin{array}{l}\text { Very good uniformity of content; } \\
\text { Simple technique, low opera- } \\
\text { tional costs. }\end{array}$ & $\begin{array}{l}\text { Calcium silicate; Magne- } \\
\text { sium aluminosilicate; } \\
\mathrm{SiO}_{2} \text {; carbone nanotubes. }\end{array}$ \\
\hline Melt extrusion & $\begin{array}{l}\text { Semisolid formulations are extruded after } \\
\text { fusion in order to obtain a product with } \\
\text { uniform density and shape. }\end{array}$ & $\begin{array}{l}\text { High APIs loading; } \\
\text { good uniformity of content; } \\
\text { Suitable for low dosed strong } \\
\text { APIs. } \\
\text { No solvent is needed. }\end{array}$ & $\begin{array}{l}\text { Solutol HS-15.; } \\
\text { PEG-30-di-(polyhydro- } \\
\text { xystearate) } \\
\text { Gelatin; } \\
\text { microcrystalline cellu- } \\
\text { lose, Gelucire® 44/14, } \\
\text { hypromellose, ethyl- } \\
\text { cellulose }\end{array}$ \\
\hline $\begin{array}{l}\text { Spray drying } \\
\text { and spray } \\
\text { cooling }\end{array}$ & $\begin{array}{l}\text { Formulation of lipids, solid carriers, } \\
\text { surfactants and APIs is spray dried or } \\
\text { spray cooled; can work with dry emul- } \\
\text { sions. }\end{array}$ & $\begin{array}{l}\text { Simple process; method for dry } \\
\text { emulsion preparation that are } \\
\text { stable, no organic solvents are } \\
\text { needed. }\end{array}$ & $\begin{array}{l}\text { MCT, sugar, gelatine, } \\
\text { silicon dioxide, Polyoxyl } \\
\text { glycerides }\end{array}$ \\
\hline $\begin{array}{l}\text { Pelletisation or } \\
\text { melt- } \\
\text { granulation }\end{array}$ & $\begin{array}{l}\text { One-step process, high shear mixing; } \\
\text { Depends on APIs: distribution be size } \\
\text { shape, solubility in the binding excipient; } \\
\text { melting point of and thermoplastic behav- } \\
\text { iour of the binding excipient; binding ex- } \\
\text { cipient concentration. }\end{array}$ & $\begin{array}{l}\text { Simple process (one step); } \\
\text { No solvents needed; } \\
\text { Potentially high APIs loading (up } \\
\text { to } 85 \% \text { ). }\end{array}$ & $\begin{array}{l}\text { Gelatin } \\
\text { Solutol HS-15.; } \\
\text { PEG-30-di-(polyhydro- } \\
\text { xystearate) } \\
\text { Lactose, microcrystalline } \\
\text { cellulose; silica and } \\
\text { magnesium } \\
\text { aluminometasilicate }\end{array}$ \\
\hline
\end{tabular}

\section{CHARACTERIZATION METHODS}

The characterization of SEDDS formulations is an important step towards the selection of the most suitable one:

Visual characterization. It is possible through visual inspection to evaluate SEDDS macroscopically. Upon dilution in water if an opalescent to milky dispersion is being observed a formation of a macro emulsion is suggested; micro- and nano-emulsions are clear and transparent (isotropic) instead. Using visual inspection, it is also possible to appreciate eventual precipitation of the API from SEDDS formulation. This problem can be solved by incrementation of surfactant concentration [12].

Conductimetry is used for the confirmation of the emulsion type. Positive values are typical of $\mathrm{O} / \mathrm{W}$ or $\mathrm{W} /$ $\mathrm{O} / \mathrm{W}$ type emulsions. Furthermore, this method can be used for the drug (for those that dissociate in water) migration kinetics determination through the lipid phase in the outer water medium. This means that the release kinetic from SEDDS can be measured [4].

Droplet size analysis. The size of the dispersed phase droplets depends to a great extent on the surfactant type and concentration. For micro-emulsions, it is characteristic of having dispersed phase droplets' small diameter and narrow range of diameter distribution. This promotes a better drug release and in-vivo absorption as well as stability. Widely used techniques for dispersed phase droplets' size analysis are Photon Correlation Spectroscopy, Dynamic Laser Light Scattering. Results of these studies can eventually give polydispersion index for micro- and for nano- emulsions that are low.

Zeta potential. In conventional SEDDS formulations, the charge is negative because of many free fatty acids present [13]. This characteristic is best analyzed with techniques such as Electronic Light Scattering and Laser Doppler Velocimetry(Malvern) meaning that is being determined the dispersed phase droplets velocity and thus the Zeta potential.

Viscosity. Rheological properties of SEDDS are evaluated by viscosimetry. Different viscosity values are inherent to different systems. O/W emulsions typically show low viscosity values while for W/O emulsions typically high viscosities.

Turbidimetry. Indicators that give useful information about SEDDS formulation effectiveness is the rate and extent of emulsification. A defined amount of the studied sample is added to a suitable medium such as $0.1 \mathrm{~N} \mathrm{HCl}$ aqueous solution on constant slow mixing (50 rpm) and room temperature $\left(20-25^{\circ} \mathrm{C}\right)$. Since Self-emulsification process is too quick, the change of turbidity of the forming dispersion can be measured. The measurements can be done nephelometrically or spectrophotometrically by selecting the right wavelength in the visible spectra $(502 \mathrm{~nm})$ such that the components of the formulation do not absorb, then the percentage of passed light is determined against distilled water as blank. This technique can be applied and for emulsion stability evaluation [13, 20, 21, 22]. 
Content of API. A capsule of the studied formulation is put in $100 \mathrm{ml}$ extraction flask with solvent. It is shaken for $1 \mathrm{~h}$ by means of thermostated shaking apparatus then it is let to stand for $24 \mathrm{~h}$. The supernatant is filtered through a paper filter $(0,45 \mu \mathrm{m})$ the filtrate is being analyzed by a suitable methodology.

Thermodynamic stability. Incompatibilities between API and lipid excipients and between formulation and capsule shell (mostly used dosage form). Eventually, API precipitation probability is being evaluated, phase separation, loss of elasticity of the capsule shell, all factors that can compromise the effectiveness. An elegant protocol could be testing the samples under "extreme" conditions: high and low temperatures cycles and centrifugation. The samples that show no phase separation are selected [23].

Extent of dispersibility. A standard Apparatus II is used for this study. $1 \mathrm{ml}$ of every sample is added to 500 $\mathrm{ml}$ of water at $37 \pm 0.5^{\circ} \mathrm{C}$. The paddles are rotated at 50 $\mathrm{rpm}$. A visual evaluation can be determined:

- Level "A" - fast emulsification (1min max) - clear to a bluish solution - nanoemulsion

- Level "B" - fast emulsification (1min max)- unclear, opalescent solution - microemulsion

- Level "C" - fast emulsification (2min max)milky dispersion - coarse emulsion

- Level "D" - slow emulsification (more than $2 \mathrm{~min}$ )- yellowish greyish dispersion, grease consistency

Cytotoxicity study. Prior to the cell transport studies and in vivo pharmacokinetics, it is necessary to determine the optimal dose of API and eventual excipient toxicity as well. The cytotoxicity can depend on both substances' nature and quantity. Karamustafa et al. [2] reported a study of the effect of some absorption enhancers and $\mathrm{Na}$ Alendronate, both by quantity and contact time using cell L-929 since for this API are proper side effects such as esophagitis. Other cell lines that are used in these studies are Caco-2 [25], Balb/3T 3 or Wi-38 (ISO 10993 part 5/1999)

Cell transport studies. Caco-2 cell lines are widely used in studies evaluating cell transport of API through GIT epithelium. This cell line differentiates into cells which morphology is very similar to enterocytes'; some studies have shown that are capable of mucin synthesis [26].

In vitro release. Eur.Ph. 2.9.3 Dissolution Apparatus loaded with pH 6.8 buffer solution is a standard tool for in vitro release studies (simulated gastric $\mathrm{pH} 1.2$ fluid is used as well). Another procedure include using Franz diffusion cell (dialysis method) with pH6.8 buffer solution. This method is based on the principle that the dialysis membrane retains lipid drops and release the solubilized API only.

Although these are standard procedures, it is difficult to practically evaluate the different influence between the lipid formulation and the dialysis membrane that might have on the release process [27]. An elegant approach that can compensate for this weakness and at the same time to give valuable information could be calculating the distribution coefficient between SEDDS/ release medium by solubility determinations in both.

Since lipids are digested and processed in GIT to a different extent, it is important that the study design be as close possible to the real release conditions.

In vivo studies. Lab breaded rats are largely used in SEDDS formulation pharmacokinetic studies. The animals are breaded in normal laboratory conditions according to ethical norms and requirements for this type of studies. Usually, the rats are divided into two or more groups and one is control. To the control group is administered a dose of the model API via conventional dosage form and to the others SEDDS-API. Blood samples are taken on previously established time intervals and then are processed. The serum obtained is analyzed via a validated method (HPLC) for $\mathrm{C}_{\max }, \mathrm{T}_{\max }$ and $\mathrm{AUC}_{24 \mathrm{~h}}$ calculations. Xiaole Qi et al. [25] have reported over 2.5 times $\mathrm{AUC}_{24 \mathrm{~h}}$ incrementation of Pimotidot included in SEDDS formulation.

\section{CHARACTERISTICS OF SEDDS CLASSES}

As every other drug delivery system, SEDDS have both positive and negative characteristics that have to be taken into account during the development phase. Different SEDDS can be classified based on their typical properties. These can be summarized in the following table:

Table 3. Comparison of the basic SEDDS classes characteristics [32, 33]

\begin{tabular}{|l|l|l|}
\hline \multicolumn{1}{|c|}{ SEDDS } & \multicolumn{1}{|c|}{ Micro-SEDDS } & \multicolumn{1}{c|}{ Nano-SEDDS } \\
\hline $\begin{array}{l}\text { Simple binary systems of APIs and } \\
\text { excipients that are capable of self-emul- } \\
\text { sification when in contact with GIT flu- } \\
\text { ids or system of APIs, surfactant and } \\
\text { oil/s. }\end{array}$ & $\begin{array}{l}\text { Systems of APIs, surfactants/co- } \\
\text { surfactants, oils. }\end{array}$ & $\begin{array}{l}\text { Systems of APIs, surfactants/co- } \\
\text { surfactants and or co-solvents, oils. }\end{array}$ \\
$\begin{array}{l}\text { The oil drops of the dispersion can } \\
\text { reach dimensions in the range of } 200 \\
\text { nm - 5 } \mu \text { m. }\end{array}$ & $\begin{array}{l}\text { The oil drops of the dispersion reach } \\
\text { dimensions in range of up to 200 nm } \\
\text { Macroscopically a cloudy dispersion is } \\
\text { observed. }\end{array}$ & $\begin{array}{l}\text { Macroscopically a clear to slightly drops of the dispersion reach } \\
\text { opalescent dispersion is observed } \\
\text { dimensions in range of up to } 100 \mathrm{~nm} \\
\text { Macroscopically a clear to dispersion } \\
\text { is observed. }\end{array}$ \\
\hline
\end{tabular}




\begin{tabular}{|c|c|c|}
\hline $\begin{array}{l}\text { These systems are not thermodynami- } \\
\text { cally stable when in contact with wa- } \\
\text { ter or GIT fluids. } \\
\text { Formulation and optimization may re- } \\
\text { quire phase diagrams construction. }\end{array}$ & $\begin{array}{l}\text { These systems are thermodynamically } \\
\text { stable when in contact with water or } \\
\text { GIT fluids. } \\
\text { Formulation and optimization require } \\
\text { phase diagrams construction. }\end{array}$ & $\begin{array}{l}\text { These systems are thermodynamically } \\
\text { stable when in contact with water or } \\
\text { GIT fluids. } \\
\text { No phase separation is observed. } \\
\text { Formulation and optimization require } \\
\text { phase diagrams construction. }\end{array}$ \\
\hline
\end{tabular}

(APIs- active pharmaceutical ingredients; GIT- gastro intestinal)

Table 4.Advantages and disadvantages of SEDDS [28]

\begin{tabular}{|l|l|}
\hline \multicolumn{1}{|c|}{ ADVANTAGES } & \multicolumn{1}{c|}{ DISADVANTAGES } \\
\hline Fast action & $\begin{array}{l}\text { Usually unconventional for API solubilization methods } \\
\text { are used. } \\
\text { APIs dose lowering } \\
\text { Bioavailability improvement } \\
\text { Simple production }\end{array}$ \\
$\begin{array}{l}\text { Potential for peptide APIs that are not stable in GIT } \\
\text { In many cases GIT digesting processes are not affecting } \\
\text { these systems }\end{array}$ & $\begin{array}{l}\text { Ascertainment of exact and reproducible IVIV correlation } \\
\text { is needed. } \\
\text { High APIs loading capacity }\end{array}$ \\
& $\begin{array}{l}\text { tants high concentrations can cause f adverse GIT reac- } \\
\text { tions }\end{array}$ \\
\hline
\end{tabular}

(APIs- active pharmaceutical ingredients; GIT- gastro intestinal; IVIV- in vitro-in vivo)

\section{CONCLUSION}

Without any doubt, SEDDS present a wide spectrum of formulation pathways for APIs classified in the "problematic" BCS classes. They are well tolerated and present fewer side effects. Evidence for this statement is the growing number of authorized drug products using this technology worldwide.

A challenge still standing is to amplify the spectrum of APIs that can be incorporated in this type of DDS. Another direction in which a lot of work has to be done is on the development of validated in vitro model for this type of DDS that realistically can predict in vivo behaviour and destiny of SEDDS while is simple and available.

Another important task to be accomplished is the standardization of the experimental design in order to reduce the variation in the obtained results $[30,31]$

\section{REFERENCES:}

1. Amidon GL, Lennernas H, Shah VP, Crison JR. A theoretical basis for a biopharmaceutic drug classification: the correlation of in vitro drug product dissolution and in vivo bioavailability. Pharm Res. 1995 Mar; 12(3):413-20. [PubMed] [Crossref]

2. Sachin M, Arun T, Pradeep P, Jineetkumar B. Development and Evaluation of Solid Self Double Emulsifying Drug Delivery System (SSDEDDS): A Novel Approach to Enhance Bioavailability of BCS Class III Drugs. J Pharm Res. 2016 Jun; 10(6):403-09.

3. Padole A, Bodhankar M. Selfdouble emulsifying drug delivery system (SDEDDS): a review. JDDT. 2012 Nov;2(6):124-27. [Crossref]

4. Tirnaksiz F, Kalsin O. A Topical
W/O/W Multiple Emulsions Prepared With Tetronic 908 as a Hydrophilic Surfactant: Formulation, Characterization and Release Study. J Pharm Pharm Sci. 2005 Aug;8(2):299-315. [PubMed]

5. Pouton CW. Formulation of selfemulsifying drug delivery systems. ADDR. 1997 April 14;25(1):47-58. [Crossref]

6. Pal VK. Self emulsifying drug delivery system. JPRO. 2011 Aug; 1(3):80-84.

7. Kalepu S, Manthina M, Padavala V. Oral lipid-based drug delivery systems- an overview. APSB. 2013 Dec;3(6): 361-72 [Crossref]

8. Chistie WW. High Performance Liquid Chromatography and Lipids: a Practical Guide. 1st ed, Oxford:
Pergamon Press, 1987; p.5

9. Small DM. A Classification of Biologic Lipids Based Upon Their Interaction in Aqeous Systems. J Am Oil Chem Soc. 1968 Mar;45(3):108-19. [PubMed] [Crossref]

10. Griffin WC. Classification of Surface-Active Agents by "HLB". J Cosmet Sci. 1949; 1:311-26. [Internet]

11. Pouton C W. Lipid formulations for oral administration of drugs: nonemulsifying, self-emulsifying and 'self-microemulsifying' drug delivery systems. Eur J Pharm Sci. 2000 Oct;11 Suppl. 2:S93-8. [PubMed] [Crossref]

12. Akula S, Gurram AK, Devireddy SR. Self-Microemulsifying Drug Delivery Systems: An Attractive Strategy for Enhanced Therapeutic 
Profile. Int Sch Res Notices. 2014 Dec 8;2014:964051. [PubMed] [Crossref]

13. Pattewar S, Kasture S, Pande V, Sharma S. Self Microemulsifying Drug Delivery System: A Lipid Based Drug Delivery System. Int J Pharm Sci Res. 2016 Feb;7(2):443-52. [Crossref]

14. Ahmad J, Amin S, Kohli K, Mir SR. Construction of Pseudoternary Phase Diagram and its Evaluation: Development of Self-dispersible Oral Formulation. Int J Drug Dev \& Res. 2013 Apr-Jun;5(2):84-90.

15. Agrawal S, Giri TK, Tripathi DK, Alexander A, Alexander A. A review on Novel Therapeutic Strategies for the Enhancement of Solubility for Hydrophobic Drugs through Lipid and Surfactant Based Self Micro Emulsifying Drug Delivery System: A novel Approach. Am J Drug Discov Dev. 2012; 2(4):143-83. [Crossref]

16. Kolhe SM, Patil AT, Bawane PP, Gawad JB. Development and Evaluation of Solid Self Double Emulsifying Drug Delivery System (SSDEDDS): A Novel Approach to Enhance Bioavailability of BCS Class III Drugs. JPR. 2016; 10(6): 403-9.

17. Schmidts T, Dobler D, Nissing C, Runkel F. Influence of hydrophilic surfactants on the properties of multiple W/O/W emulsions. J Colloid Interface Sci. 2009 Oct;338(1):184-92. [PubMed] [Crossref]

18. Jannin V, Musakhanian J, Marchaud D. Approaches for the development of solid and semi-solid lipidbased formulations. Adv Drug Deliv
Rev. 2008 Mar 17;6(60):734-46; [PubMed] [Crossref]

19. Shobhit K, Gupta SK, Sharma PK. Self-Emulsifying Drug Delivery Systems (SEDDS) for Oral Delivery of Lipid Based Formulations - A Review. AJBAS. 2012; 4 (1): 07-11.

20. Fletcher PDI, Morris JS. Turbidity of oil-in-water microemulsion droplets stabilised by nonionic surfactants. Colloids Surf A Physicochem Eng Asp. 1995 May; 98(12):147-54. [Crossref]

21. Roland I, Piel G, Delattre L, Evrard B. Systematic characterization of oil-in-water emulsions for formulation design. Int J Pharm. 2003 Sep 16;263(1-2):85-94. [PubMed]

22. Rukmini A, Raharjo S, Hastuti P, Supriyadi S. Formulation and stability of water-in-virgin coconut oil microemulsion using ternary food grade nonionic surfactants. Int Food Res J. 2012; 19(1):259-64.

23. Pal VK. Self emulsifying drug delivery system. JPRO. 2011 Aug; 1(3):80-84.

24. Karamustafa F, Celebi N. Development of an oral microemulsion formulation of alendronate: Effects of oil and co-surfactant type on phase behaviour. J Microencapsul. 2008 Aug; 25(5):315-23. [PubMed] [Crossref]

25. Qi X, Wang L, Zhu J, Hu Z, Zhang J. Self-double-emulsifying drug delivery system (SDEDDS): A new way for oral Delivery of drugs with high solubility and low permeability. Int $J$ Pharm. 2011 May 16;409(1-2):245-

\section{1. [PubMed] [ $\underline{\text { Crossref }}]$}

26. Han H-K, Shin H-J, Ha DH. Improved oral bioavailability of alendronate via the mucoadhesive liposomal delivery system. Eur J Pharm Sci. 2012 Aug 15;46(5):500-7. [PubMed] [Crossref]

27. Bernkop-Schnürch A, Jalil A. Do drug release studies from SEDDS make any sense? J Control Release. 2018 Feb 10;271:55-9. [PubMed] [Crossref]

28. Nigade PM, Patil SL, Tiwari SS. Self-emulsifying drug delivery system (SEDDS): A Review. IJPBS. 2012 AprJune;2(2):42-52.

29. Feeney OM, Crum MF, McEvoy CL, Trevaskis NL, Williams HD, Pouton CW, et al. 50years of oral lipid-based formulations: Provenance, progress and future perspectives. $A d v$ Drug Deliv Rev. 2016 Jun 1;101:16794. [PubMed] [Crossref]

30. Shrestha H, Bala R, Arora S. Lipid-Based Drug Delivery Systems. J Pharm (Cairo). 2014; 2014:801820. [PubMed] [Crossref]

31. Chavda VP. Are SMEDDs and SNEDDs same? A gimmick or pharmaceutically relevant. MJPMS. 2012 Oct-Dec;1(1):7-10.

32. Gupta S, Kesarla R, Omri A. Formulation Strategies to Improve the Bioavailability of Poorly Absorbed Drugs with Special Emphasis on SelfEmulsifying Systems. ISRN Pharm. 2013 Dec 26;2013:848043. [PubMed] [Crossref]

Please cite this article as: Pehlivanov I. Self-Emulsifying Drug Delivery Systems (SEDDS): Excipient selection, formulation and characterization. J of IMAB. 2020 Jul-Sep;26(3):3226-3233. DOI: https://doi.org/10.5272/jimab.2020263.3226

Received: 20/08/2019; Published online: 08/07/2020

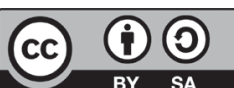

Address for correspondence:

Ivaylo Pehlivanov

Department of Pharmaceutical Technologies, Faculty of Pharmacy, Medical University of Varna,

84, Tzar Osvoboditel str. Medical College building, room 314 B, Varna, Bulgaria. E-mail: Ivaylo.Pehlivanov@mu-varna.bg, 